\title{
Thorny Shrubs Limit the Browsing Pressure of Large Herbivores on Tree Regeneration in Temperate Lowland Forested Landscapes
}

\author{
Lubomir Salek $^{1}$, Jaromir Harmacek ${ }^{2}$, Lucie Jerabkova ${ }^{3}{ }^{\mathbb{D}}$, Osman Topacoglu ${ }^{4}$ and \\ Ivo Machar $2, *$ (D) \\ 1 Department of Forest Management, Faculty of Forestry and Wood Sciences, Czech University of Life \\ Sciences in Prague, 16500 Praha 6-Suchdol, Czech Republic \\ 2 Faculty of Science, Department of Development and Environmental Studies, Palacky University Olomouc, \\ 77147 Olomouc, Czech Republic \\ 3 Department of Geography, King's College London, London WC2R 2LS, UK \\ 4 Faculty of Forestry, Department of Forest Engineering, Kastamonu University, 37000 Kastamonu, Turkey \\ * Correspondence: ivo.machar@upol.cz
}

Received: 29 May 2019; Accepted: 27 June 2019; Published: 28 June 2019

\begin{abstract}
Thorny shrubs are considered as an important driver in the natural development of temperate forest structures, particularly in European lowland forests. We assessed the current role of thorny shrubs in the regeneration of deciduous tree species under heavy browsing pressure in a central European temperate forested landscape. The study's military training area offered a unique opportunity to investigate the processes in which deciduous tree seedlings grew under thorny shrubs and in the close vicinity of thorny shrubs in a landscape with a high density of large herbivores (red deer and sika deer). We assessed the number of seedlings, species composition, seedling height, and degree of browsing damage, and their relationship to study plots elevation, thorny shrub species, coverage, and height. The regenerated tree seedlings were mostly detected as common ash (Fraxinus excelsior) and wild cherry (Cerasus avium). The species of thorny shrubs were blackthorn (Prunus spinosa), hawthorn (Crataegus sp.), and wild rose (Rosa sp.). We found that the thorny shrubs protected the tree seedlings from browsers to a large extent. However, the effects of thorny shrubs on the tree seedlings' characteristics varied among the shrub species. While results revealed significant effects of hawthorn and wild rose on the tree seedlings' abundance and survival, blackthorn's negative effect of shading the tree seedlings outweighed its protective role. These results indicated a possible mechanism that enabled the regeneration of deciduous tree species under large herbivore pressure. These results can be applied in the landscape planning and forest management of deciduous tree regeneration and forest restoration in temperate forested lowland landscapes, where high densities of large herbivores (without the presence of large predators) usually occur.
\end{abstract}

Keywords: browsing; red deer; military training area; forest regeneration; sika deer; thorny shrubs; Vera's theory

\section{Introduction}

As reforestation and forest restoration grow in importance in Europe and around the world [1], the debate concerning the appropriate reference points and ecological conditions continues to evolve [2,3]. The development of the landscape matrix in the European temperate zone after the last Ice Age [4] was thought to have been dominated by forested landscapes [5]. The well-known study of Vera [6], however, offered a historical perspective on the European temperate lowland forested landscape as an open savannah (wood-pasture landscape) maintained by large herbivores, 
such as the European bison (Bison bonasus, Linnaeus, 1758), the Eurasian wild horse (Equus ferus ferus Boddaert, 1785), and the auroch (Bos primigenius, Bojanus, 1827). Vera's theory is based on the assumption that most of light-demanding deciduous trees were not able to regenerate naturally in closed and dark mature forests. Vera distinguished four phases of open-landscape development. The first phase was an open, savanna-like phase with scattered, very large trees. This phase was followed by a shrub phase with the spread of thorny shrubs, which provided a shelter for tree seedlings and young trees against the browsing of large herbivores. Later, the tree-dominated phase followed, during which shrubs disappeared from the shaded closed mature forest, and large herbivores returned and prevented tree regeneration. The final stage was the break-up phase, in which the canopy opened up as mature trees died. Thus, large herbivores and thorny shrubs can be considered as the crucial drivers of the temperate European lowland forest ecosystem history. The study of Birks [7] proposed a rejection of Vera's hypothesis based on a comparison with competitive hypotheses, e.g., [8]. Bakker et al. [9] presented multiple evidences of large changes in vegetation structures around the world after the extinction of large herbivores, with a tendency towards a higher occurrence of woody plants and less open landscapes. Some authors highlighted the neglecting of the ecological effects of large carnivores as an important shortcoming of Vera's theory [10]. Generally, this theory has been widely debated [11,12], but there is difficulty to test it under current natural conditions, as the European lowland landscape has changed substantially [13-15].

The ecological role of large herbivores in today's temperate European lowland forested landscapes depends predominantly on the herbivore density $[16,17]$. A low density of large herbivores can be associated with a high diversity of invertebrate species of conservation concern in lowland managed hardwood forests, as pointed out in study [18] from the Czech Republic. Some studies suggested the return of forest browsing by large herbivores, including cattle [19], in temperate European lowland hardwood forests as a tool for the conservation of invertebrate diversity [20]. On the other hand, a high large herbivore density in temperate lowland hardwood forests limits bird diversity in forest ecosystems, especially in guilds of bird nesters in the understorey and shrub layers [21]. The understorey foliage in lowland forest ecosystems in England is significantly reduced by high deer density, with significant negative impacts on forest regeneration and biodiversity [22]. The effects of large herbivore browsing pressure on lowland forest biodiversity are aggravated due to the absence of large predators in the prevailing areas of lowland European cultural landscapes [23].

Large herbivores influence the survival of seedlings and sapling growth in forested lowland landscapes [24]. Based on many other factors (soils, competition, etc.), the density of shrubs probably plays an important role in the survival of deciduous tree species under browsing pressure $[25,26]$. Some temperate deciduous tree species also regenerated vegetatively by layering or suckering, which can be more robust strategies than regeneration from seeds in the conditions of browsing by large herbivores [27]. Generally, there are still important knowledge gaps in our understanding of the relationships among large herbivore density (and browsing pressure), thorny shrubs [28], and the natural regeneration of temperate lowland forests [29]. Forest management decisions at the site level must include the large herbivore browsing pressure in decision making [30-32]. The aim of this study was to test the effects of large herbivores and thorny shrubs on tree regeneration in a current landscape in order to understand how patterns may have played a key role. Furthermore, knowledge of these patterns can be used as a decision support tool in the restoration management of lowland forest ecosystems, and in re-starting the natural regeneration of diverse tree communities under browsing pressure of large herbivores (if large carnivores are absent). This is a reason why our study focused on the current ecological interactions between large herbivores and thorny shrubs in a temperate European lowland forested landscape.

We found a suitable study area for this research in the western part of the Czech Republic: A military training area (MTA). In central European landscapes, military training has caused frequent and irregular disturbances, followed in succession by thorny shrub growth and forest vegetation. This succession generated a fine-scaled mosaic of different types of habitats. Recently, awareness of MTAs 
as important biodiversity refuges has increased [33,34]. In contrast with studies which have presented the results of interactions between large domesticated herbivores and the regeneration of forest tree species [35,36], our study aimed to reveal the interactions among large wild herbivores, thorny bushes, and the natural regeneration of forest tree species. The aim of this study was to test the effects of large herbivores and thorny shrubs on tree regeneration in a current landscape in order to understand how patterns may play a key role. Furthermore, knowledge of these patterns can be used as a decision support tool in the restoration management of lowland forest ecosystems, and in re-starting the natural regeneration of diverse tree communities under browsing pressure from large herbivores.

We defined the hypothesis as: "Thorny shrubs play an important role in the protection of deciduous tree regeneration against browsing by large wild herbivores". To test the hypothesis, we used regression analysis and investigated the determinants of: (i) The probability of tree species regeneration; (ii) the heights of seedlings and saplings; and (iii) the proportions of seedlings and saplings damaged by browsing of large herbivores.

\section{Materials and Methods}

\subsection{Study Area and Study Plots Design}

The study was conducted in the Military Training Area (MTA) named Hradiste, located in the western part of the Czech Republic close to the border with Germany. The area of the MTA was $330.15 \mathrm{~km}^{2}$. The local inhabitants were forced to move out at the end of WWII, and the area was converted into an MTA. The open areas were maintained tree-less and used for army training, such as target practice for the air force, tank units, and infantry. After 1989, army activities were ended and the area was abandoned. The processes of natural succession were developed $[37,38]$. Since the area has been abandoned, thorny shrubs, wild rose (Rosa spp.) hawthorn (Crataegus spp.), and blackthorn (Prunus spinosa L.) have dominated. At the same time, the local populations of two species of large herbivores-red deer (Cervus elaphus Linnaeus, 1758) and sika deer (Cervus nippon Temminck, 1838) - have become very high: While the normal stock of red deer in the whole area would be only 125 individuals, the spring stock in the year 2000 of red deer was 390 individuals, and for sika deer it was 281 individuals [39]. Records from a large herbivore census showed an average annual population density of 1.53 individual sika deer per 100 ha, and 1.41 individual red deer per 100 ha [40]. As dietary overlap between red deer and sika deer in the study area is very high [41,42], we did not take into account that red deer is a native species while sika deer was introduced in 1920 . The environmental conditions are characterised by an average annual temperature of $6.8^{\circ} \mathrm{C}$ and an average annual precipitation of $632 \mathrm{~mm}$. The elevation on the MTA varies from 380 to $934 \mathrm{~m}$ a.s.l. (the highest peak). The main soil types are mesotrophic and eutrophic cambisols. The forest structure has changed over history, and the present forests are formed mainly by Norway spruce (Picea abies (L.) Karsten), pine (Pinus sylvestris L.), larch (Larix decidua Mill.), and beech (Fagus sylvatica L.). On abandoned segments, grove and scattered mature trees were formed by maples (Acer spp.), lime (Tilia spp.), beech, oak (Quercus robur L.), ash (Fraxinus excelsior L.), cherry tree (Prunus avium L), aspen (Populus tremula L.), and willow (Salix sp.).

We identified large abandoned forest-free areas in the MTA (total surface of approximately $200 \mathrm{ha}$ ), and divided each area into a regular grid of squares of $50 \times 50 \mathrm{~m}$. Based on the aerial pictures and forest maps, the intersections of the grid were selected so that the distance from a seed source tree would not exceed $100 \mathrm{~m}$. After this primary selection, the plots were numbered, and 40 plots were selected using a pseudorandom number generator. The sample plots were squares of $10 \times 10 \mathrm{~m}$, and their centres were located in the selected nodes. We recorded the elevations of the plots and then the thorny shrub species, thorny shrub composition (proportion of cover), shrub cover, average shrub height, number of seedlings $(<0.5 \mathrm{~m})$ and saplings $(0.5-5 \mathrm{~m})$ for every forest tree species, seedling composition (proportions) and height, damage from browsing (from $0 \%$ to $100 \%$, between undamaged and damaged seedlings and saplings), and distance of plot centre from a possible seed source. Any 
visible damage caused by large herbivores (either on terminal shoots or branches) meant classification as damaged seedlings or saplings from browsing. Seed trees were checked for the presence of seeds in their crowns.

\subsection{Data Analysis}

We used the Pearson correlation analyses to create a 3-by-7 table of correlation coefficients that measured the strengths of associations between the variables we were interested in. These were: Number of seedlings and saplings from forest trees, heights of seedlings and saplings, and damage from browsing on the one side; and elevation of a unit area, heights of shrubs, shrub cover, distance from seed source, wild rose proportion, hawthorn proportion, and blackthorn proportion on the other side. To investigate the relationship between the heights of seedlings and saplings (HSS) and the heights of shrubs, we had to take into account that the HSS is likely to be affected by the browsing of large herbivores. Therefore, in this specific case, as a control for the damage from browsing, we employed a regression analysis which took the form of HSS $=a$ (coefficient of intercept) $+b_{1}$ (heights of shrubs) $+b_{2}$ (damage from browsing). We estimated the parameters $a, b_{1}$, and $b_{2}$ using the ordinary least squares (OLS) with robust standard errors.

In the main part of the analyses, we used different regression models to examine the relationships that we were interested in. First, we analysed factors that influence the probability of non-zero regeneration (there were no tree seedlings and saplings in seven plots). We created a "dummy variable" with the value of 1 if there was any regeneration, and the value of 0 if there was no regeneration in the plot. We then used logit regression. Second, we tested the determinants for the number of regenerated tree seedlings and saplings. The number of tree seedlings and saplings was the dependent variable in this analysis. We included 39 plots in the analysis, as there was a clear outlier (the number of seedlings and saplings in this plot was $56 \%$ of all seedlings and saplings). Since the dependent variable was expressed in non-negative numbers (counts), we used the Poisson regression method. Next, we tested the determinants of the tree seedling and sapling heights. We used a two-step regression model because the heights of tree seedlings and saplings can only be explained for a non-zero number of seedlings. In the first step, using the logit method for all 40 plots, we solved factors of non-zero numbers of seedlings and saplings. In the second step, using the OLS method for only for 33 plots (with a non-zero number of seedlings and saplings), this study examined the factors influencing the heights of seedlings and saplings.

The last part of our analysis was focused on damage from browsing. We also used a two-step approach, as the damage can also be explained only for a non-zero number of seedlings and saplings. In the first step, using the logit method for all 40 plots, we solved the factors of a non-zero number of seedlings and saplings. In the second step, the dependent variable, the proportion of damaged tree seedlings and saplings, could take values from 0 to 1 . To perform an OLS regression, we had to transform the variable using the logit transformation. Before the transformation, we replaced the values 0 and 1 (which are not defined in the transformation) with numbers close to them (0.001 and 0.999). We analysed data from 33 plots because there was no regeneration in seven of the plots.

We used the statistical software Stata 15 [43] for all analyses. Throughout all regression models, we worked with the same set of explanatory variables: Elevation of a unit area, heights of shrubs, shrub cover, distance from seed source, and the composition of the shrub species (wild rose, hawthorn, and blackthorn). The composition of shrub species was first entered into the regressions individually (one by one), and then in pairs in all three possible combinations (hawthorn with wild rose, hawthorn with blackthorn, and wild rose with blackthorn). This resulted in six specifications for each regression model. We estimated all specifications and models using robust standard errors to correct for slight deviations from the standard regression assumptions of the homoscedasticity and normality of residuals. 


\section{Results}

We determined eight species of regenerated broadleaved trees. Common ash (Fraxinus excelsior L.) was the most abundant and constituted $84.4 \%$ of trees or shrubs, followed by cherry (Prunus avium L.) $-4.9 \%$, sycamore maple (Acer pseudoplatanus L.) - 3.6\%, common hazel (Corylus avellana L.) - $2.1 \%$, field maple (Acer campestre L.) - 1.7\%, aspen (Populus tremula L.) - 1.4\%, Norway maple (Acer platanoides L.) $-1.1 \%$, and beech (Fagus sylvatica L.) $-0.9 \%$.

The most abundant thorny shrub was hawthorn (Crataegus spp.), comprising 53.5\% of shrubs in the plot, then blackthorn (Prunus spinosa L.) - 23.1\% and wild rose (Rosa spp.) - 23\%. The total thorny shrub cover ranged from $20 \%$ to $100 \%$ (Table 1 ).

Table 1. Summary statistics for the dependent and explanatory variables.

\begin{tabular}{llllll}
\hline Variable Dependent & No $^{\mathbf{1}}$ & Ave $^{2}$ & SD $^{\mathbf{3}}$ & Min & Max \\
\hline HeightS $^{4}(\mathrm{~m})$ & 40 & 0.860 & 0.801 & 0 & 3.5 \\
NumberS $^{5}$ & 39 & 28.333 & 36.540 & 0 & 144 \\
DamS $^{6}(\%)$ & 40 & 39.919 & 40.809 & 0 & 100 \\
Explanatory $_{\text {Comp hawt }}^{7}(\%)$ & 40 & 53.5 & 39.227 & 0 & 100 \\
Comp rose $^{8}(\%)$ & 40 & 23.0 & 31.149 & 0 & 100 \\
Comp black $^{9}(\%)$ & 40 & 23.125 & 38.141 & 0 & 100 \\
Hh $^{10}(\mathrm{~m})$ & 40 & 2.9 & 1.359 & 1.2 & 7.3 \\
Cover $^{11}(\%)$ & 40 & 77.125 & 21.952 & 20 & 100 \\
Elevation $^{12}(\mathrm{~m})$ & 40 & 626.5 & 82.541 & 480 & 800 \\
DistTree $^{13}(\mathrm{~m})$ & 40 & 52.925 & 56.147 & 0 & 100 \\
\hline
\end{tabular}

${ }^{1}$ Number of plots (No), ${ }^{2}$ average (Ave), ${ }^{3}$ standard deviation (SD), ${ }^{4}$ heights of seedlings (HeightS), ${ }^{5}$ number of seedlings and saplings per $100 \mathrm{~m}^{2}$-one plot (NumberS), ${ }^{6}$ proportion of damaged seedlings and saplings (DamS), ${ }^{7}$ hawthorn composition (Comp hawt), ${ }^{8}$ wild rose composition (Comp rose), ${ }^{9}$ blackthorn composition (Comp black), ${ }^{10}$ heights of shrubs (Hh), ${ }^{11}$ shrub cover (Cover), ${ }^{12}$ plot elevation (Elevation), and ${ }^{13}$ distance from seed source-maternal trees (DistTree).

The correlation analyses between the number of seedlings and saplings, and thorny shrub characteristics showed that the number of seedlings and saplings correlated positively with the hawthorn composition and negatively with the blackthorn composition. In seven plots, there were no tree seedlings and saplings, and of those, five were plots with dominant blackthorn, which covered between $90 \%-100 \%$. The percentage of seedling and sapling damage showed the same relationship (Table 2). The occurrence of wild rose positively correlated with the heights of seedlings and saplings.

Table 2. Bilateral correlation coefficients (with $p$-values in parentheses) among the explanatory variables and the dependent variables.

\begin{tabular}{|c|c|c|c|}
\hline Variables & NumberS $^{1}$ & HeightS $^{2}$ & DamS $^{3}$ \\
\hline Elevation ${ }^{4}$ & $-0.244(0.135)$ & $0.333(0.038)$ & $0.119(0.503)$ \\
\hline Comp hawt ${ }^{5}$ & $0.499(0.001)$ & $-0.084(0.612)$ & $0.436(0.009)$ \\
\hline Comp rose 6 & $-0.180(0.274)$ & $0.412(0.009)$ & $0.005(0.978)$ \\
\hline Comp black $^{7}$ & $-0.366(0.022)$ & $-0.247(0.130)$ & $-0.459(0.006)$ \\
\hline $\mathrm{Hh}^{8}$ & $0.366(0.022)$ & $-0.251(0.124)$ & $0.191(0.280)$ \\
\hline Cover $^{9}$ & $0.252(0.121)$ & $-0.209(0.201)$ & $-0.254(0.148)$ \\
\hline DistTree ${ }^{10}$ & $-0.103(0.532)$ & $0.031(0.854)$ & $-0.040(0.822)$ \\
\hline
\end{tabular}

${ }^{1}$ Number of seedlings and saplings (NumberS), ${ }^{2}$ heights of seedlings and saplings (HeightS), ${ }^{3}$ proportion of damaged seedlings and saplings (DamS), ${ }^{4}$ plot elevation (Elevation), ${ }^{5}$ hawthorn composition (Comp hawt), ${ }^{6}$ wild rose composition (Comp rose), ${ }^{7}$ blackthorn composition (Comp black), ${ }^{8}$ heights of shrubs (Hh), ${ }^{9}$ shrub cover (Cover), and ${ }^{10}$ distance from seed source (maternal trees) (DistTree).

We were also interested in the relationship between the heights of seedlings and saplings (HSS) and the heights of thorny shrubs. The bilateral correlation was negative but marginally insignificant at the $10 \%$ level. However, when we controlled for the damage from browsing using the OLS regression with robust standard errors, we discovered that the relationship between HSS and heights of shrubs 
was negative and statistically highly significant at the $1 \%$ level, with a coefficient of -0.103 and a $p$-value of 0.009 . The relationship between damage from browsers and heights of seedlings and saplings was statistically insignificant.

Next, we focused on the determinants of tree species regeneration, heights of seedlings and saplings, and finally, on the proportion of seedlings and saplings damaged by large herbivores. On average (and in most models), the probability of tree species regeneration grew as the cover of thorny shrubs increased and as the proportion of hawthorn and wild rose increased. The probability fell with a higher proportion of blackthorn and with longer distances from seed source trees (Table 3). Elevation had no effect on the probability of regeneration. The number of seedlings and saplings positively correlated with shrub heights in all models and with total thorny shrub coverage (give models). It was also evident that the higher the proportion of hawthorn, the higher the number of seedlings and saplings. (Table 4).

Table 3. Factors of probability of tree species regeneration, expressed by logit regression coefficients for six models.

\begin{tabular}{|c|c|c|c|c|c|c|}
\hline Models & Mod1 & Mod2 & Mod3 & Mod4 & Mod5 & Mod6 \\
\hline Variables & Black & Hawt & Rose & Hawt+Rose & Hawt+Black & Black+Rose \\
\hline Elevation $^{1}(\mathrm{~m})$ & 0.001 & 0.001 & -0.011 & -0.004 & -0.004 & -0.004 \\
\hline Comp hawt ${ }^{2}$ & & $0.040 * *$ & & $0.099 * * *$ & -0.046 & \\
\hline Comp rose ${ }^{3}$ & & & $0.130 * *$ & $0.146^{* * *}$ & & 0.046 \\
\hline Comp black ${ }^{4}$ & $-0.096^{* * *}$ & & & & $-0.145^{* * *}$ & $0.099 * * *$ \\
\hline $\mathrm{Hh}^{5}(\mathrm{~m})$ & 0.009 & 0.461 & $1.655^{* *}$ & -0.003 & -0.004 & -0.004 \\
\hline Cover ${ }^{6}$ & $0.085^{* * *}$ & -0.032 & -0.004 & $0.126^{* *}$ & $0.125^{* *}$ & $0.125^{* *}$ \\
\hline DistTree $^{7}(\mathrm{~m})$ & $-0.025^{* *}$ & -0.011 & -0.030 ** & $-0.028 * * *$ & $-0.028 * * *$ & $-0.028 * * *$ \\
\hline No obs 8 & 40 & 40 & 40 & 40 & 40 & 40 \\
\hline Const. & 1.519 & 1.487 & 4.398 & -0.089 & 4.508 & -10.001 \\
\hline Pseudo $R^{2}$ & 0.589 & 0.332 & 0.326 & 0.610 & 0.611 & 0.611 \\
\hline Wald $\mathrm{Chi}^{2}$ & $27.03^{* * *}$ & $9.81 *$ & 5.36 & $26.08^{* * *}$ & $25.54 * * *$ & $25.76^{* * *}$ \\
\hline
\end{tabular}

Mod1 is blackthorn, Mod2 is hawthorn, Mod3 is wild rose, Mod4 is wild rose with hawthorn, Mod5 is hawthorn with blackthorn, and Mod6 is wild rose with blackthorn. * Significance level is $p<0.1,{ }^{* *}$ significance level is $p<0.05$, $* * *$ significance level is $p<0.01$. All regression models were estimated with robust standard errors. ${ }^{1}$ Plot elevation (Elevation), ${ }^{2}$ hawthorn composition (Comp hawt), ${ }^{3}$ wild rose composition (Comp rose), ${ }^{4}$ blackthorn composition (Comp black), ${ }^{5}$ heights of shrubs (Hh), ${ }^{6}$ shrub cover (Cover), ${ }^{7}$ distance from seed source (DistTree), ${ }^{8}$ number of observations (No obs).

Table 4. Determinants of number of seedlings and saplings of tree species, expressed by Poisson regression coefficients for six models.

\begin{tabular}{|c|c|c|c|c|c|c|}
\hline Models & Mod1 & Mod2 & Mod3 & Mod4 & Mod5 & Mod6 \\
\hline Variables & Black & Hawt & Rose & Hawt+Rose & Hawt+Black & Black+Rose \\
\hline Elevation ${ }^{1}(\mathrm{~m})$ & -0.002 & -0.003 & $-0.004^{* *}$ & -0.002 & -0.002 & -0.002 \\
\hline Comp hawt ${ }^{2}$ & & $0.015^{* * *}$ & & $0.023 * * *$ & -0.001 & \\
\hline Comp rose 3 & & & 0.005 & $0.025^{* * *}$ & & $0.002 * * *$ \\
\hline Comp black 4 & $-0.023 * * *$ & & & & $-0.024 * * *$ & $-0.023 * * *$ \\
\hline $\operatorname{Hh}^{5}(\mathrm{~m})$ & $0.195 * *$ & $0.216^{* * *}$ & $0.356^{* * *}$ & 0.203 ** & $0.197 * *$ & 0.201 ** \\
\hline Cover $^{6}$ & $0.022 * * *$ & 0.007 & $0.018^{* *}$ & $0.024^{* * *}$ & $0.023^{* * *}$ & $0.024^{* * *}$ \\
\hline DistTree $^{7}(\mathrm{~m})$ & -0.005 & -0.004 & -0.004 & -0.005 & -0.005 & -0.005 \\
\hline No obs 8 & 39 & 39 & 39 & 39 & 39 & 39 \\
\hline Const. & 2.517 & 2.932 & $3.448^{* * *}$ & 0.151 & 2.507 & 2.293 \\
\hline Pseudo $R^{2}$ & 0.447 & 0.386 & 0.272 & 0.457 & 0.447 & 0.448 \\
\hline Wald $\mathrm{Chi}^{2}$ & $35.02 * * *$ & $30.74 * * *$ & $22.80^{* * *}$ & $38.22 * * *$ & $35.28 * * *$ & $35.95^{* * *}$ \\
\hline
\end{tabular}

Mod1 is blackthorn, Mod2 is hawthorn, Mod3 is wild rose, Mod4 is wild rose with hawthorn, Mod5 is hawthorn with blackthorn, and Mod6 is wild rose with blackthorn. * Significance level is $p<0.1,{ }^{* *}$ significance level is $p<0.05$, *** significance level is $p<0.01$. All regression models were estimated with robust standard errors. ${ }^{1}$ Plot elevation (Elevation), ${ }^{2}$ hawthorn composition (Comp hawt), ${ }^{3}$ wild rose composition (Comp rose), ${ }^{4}$ blackthorn composition (Comp black), ${ }^{5}$ heights of shrubs (Hh), ${ }^{6}$ shrub cover (Cover), ${ }^{7}$ distance from seed source (DistTree), ${ }^{8}$ number of observations (No obs). 
In all models, the heights of seedlings and saplings increased with elevation and declined as the heights of shrubs increased. The presence of wild rose was a positive determinant of heights for seedlings and saplings, but it was only significant in models where hawthorn was absent. Hawthorn was a negative determinant of seedling and sapling heights, but not in models with wild rose (Table 5).

The proportion of seedlings and saplings damaged through browsing declined with higher shrub coverage. This relationship was significant in all models but one (blackthorn monoculture). The proportion of damaged seedlings and saplings also negatively correlated with the proportion of wild rose, and this relationship was significant in all models. However, in the models where wild rose was absent, the proportion of damage positively correlated with the proportion of hawthorn. The proportion of blackthorn was significant only in the model with hawthorn. Elevation was also negative and marginally significant in some of the models (Table 6).

Table 5. Determinants of heights of seedlings and saplings of tree species expressed by second-step ordinary least squares (OLS) regression coefficients (conditioned on the first-step logit regression) for six models.

\begin{tabular}{|c|c|c|c|c|c|c|}
\hline Models & Mod1 & Mod2 & Mod3 & Mod4 & Mod5 & Mod6 \\
\hline Variables & Black & Hawt & Rose & Hawt+Rose & Hawt+Black & Black+Rose \\
\hline Elevation ${ }^{1}(\mathrm{~m})$ & $0.003^{* * *}$ & $0.003^{* * *}$ & $0.003^{* * *}$ & $0.003^{* *}$ & $0.003^{* *}$ & $0.003^{* *}$ \\
\hline Comp hawt ${ }^{2}$ & & $-0.004 *$ & & -0.001 & $-0.007^{* * *}$ & \\
\hline Comp rose ${ }^{3}$ & & & $0.007 * * *$ & 0.005 & & $0.007^{* * *}$ \\
\hline Comp black ${ }^{4}$ & 0.001 & & & & -0.006 & 0.001 \\
\hline $\mathrm{Hh}^{5}(\mathrm{~m})$ & $-0.307^{* * *}$ & $-0.280 * * *$ & $-0.293 * * *$ & $-0.284^{* * *}$ & $-0.286 * * *$ & $-0.286^{* * *}$ \\
\hline Cover $^{6}$ & -0.001 & 0.002 & 0.007 & 0.006 & 0.006 & 0.006 \\
\hline DistTree $^{7}(\mathrm{~m})$ & 0.002 & 0.002 & 0.001 & 0.001 & 0.001 & 0.001 \\
\hline No obs ${ }^{8}$ & 33 & 33 & 33 & 33 & 33 & 33 \\
\hline Const. & -1.129 & -0.972 & $-1.819 * *$ & $-1.611 *$ & -1.104 & $-1.762 * *$ \\
\hline $\mathrm{R}^{2}$ & 0.497 & 0.529 & 0.543 & 0.545 & 0.549 & 0.545 \\
\hline F test & $5.34^{* * *}$ & $6.08 * * *$ & $6.42 * * *$ & $5.20 * * *$ & $5.27 * * *$ & $5.18 * * *$ \\
\hline
\end{tabular}

Mod1 is blackthorn, Mod2 is hawthorn, Mod3 is wild rose, Mod4 is wild rose with hawthorn, Mod5 is hawthorn with blackthorn, and Mod6 is wild rose with blackthorn. ${ }^{1}$ Plot elevation (Elevation), ${ }^{2}$ hawthorn composition (Comp hawt), ${ }^{3}$ wild rose composition (Comp rose), ${ }^{4}$ blackthorn composition (Comp black), ${ }^{5}$ heights of shrubs (Hh), ${ }^{6}$ shrub cover (Cover), ${ }^{7}$ distance from seed source (DistTree), ${ }^{8}$ number of observations (No obs). Significance level is $p<0.1,{ }^{* *}$ significance level is $p<0.05,{ }^{* * *}$ significance level is $p<0.01$. All regression models were estimated with robust standard errors.

Table 6. Determinants of the proportion of damaged seedlings and saplings of tree species expressed by the second-step OLS regression coefficients (conditioned on the first-step logit regression) for six models.

\begin{tabular}{ccccccc}
\hline Models & Mod1 & Mod2 & Mod3 & Mod4 & Mod5 & Mod6 \\
\hline Variables & Black & Hawt & Rose & Hawt+Rose & Hawt+Black & Black+Rose \\
Elevation $^{1}(\mathrm{~m})$ & $-0.014^{*}$ & -0.010 & $-0.013^{*}$ & $-0.012^{*}$ & $-0.013^{*}$ & -0.012 \\
Comp hawt $^{2}$ & & $0.062^{* * *}$ & & 0.020 & $0.109^{* * *}$ & \\
Comp rose $^{3}$ & & & $-0.110^{* * *}$ & $-0.091^{* * *}$ & & $-0.110^{* * *}$ \\
Comp black $^{4}$ & -0.019 & & & & $0.088^{* *}$ & -0.021 \\
Hh $^{5}(\mathrm{~m})$ & 0.652 & 0.245 & 0.435 & 0.330 & 0.339 & 0.320 \\
Cover $^{6}$ & -0.046 & $-0.089^{* *}$ & $-0.167^{* * *}$ & $-0.158^{* * *}$ & $-0.157^{* * *}$ & $-0.157^{* * *}$ \\
DistTree $^{7}(\mathrm{~m})$ & -0.015 & -0.008 & 0.005 & 0.004 & 0.003 & 0.004 \\
No obs $^{8}$ & 33 & 33 & 33 & 33 & 33 & 33 \\
Const. $_{\text {Tht }}^{*}$ & 10.926 & 8.648 & $21.934^{* * *}$ & $19.174^{* * *}$ & $10.553^{*}$ & $20.940^{* * *}$ \\
$\mathrm{R}^{2}$ & 0.154 & 0.327 & 0.418 & 0.428 & 0.426 & 0.429 \\
F test & 0.99 & $2.63^{* *}$ & $3.88^{* * *}$ & $3.24^{* *}$ & $3.15^{* *}$ & $3.26^{* *}$ \\
\hline
\end{tabular}

Mod1 is blackthorn, Mod2 is hawthorn, Mod3 is wild rose, Mod4 is wild rose with hawthorn, Mod5 is hawthorn with blackthorn, and Mod6 is wild rose with blackthorn. ${ }^{1}$ Plot elevation (Elevation), ${ }^{2}$ hawthorn composition (Comp hawt), ${ }^{3}$ wild rose composition (Comp rose), ${ }^{4}$ blackthorn composition (Comp black), ${ }^{5}$ heights of shrubs (Hh), ${ }^{6}$ shrub cover (Cover), ${ }^{7}$ distance from seed source (DistTree), ${ }^{8}$ number of observations (No obs). Significance level is $p<0.1,{ }^{* *}$ significance level is $p<0.05,{ }^{* * *}$ significance level is $p<0.01$. All regression models were estimated with robust standard errors. 


\section{Discussion}

Large herbivores steer temperate forest composition in two major ways: Preferential browsing and grazing of more palatable species such as broadleaved tree species, and intense physical disturbance such as trampling or uprooting, which can eliminate entire cohorts of seedlings and samplings from forest stands [44]. Our study confirmed the protective function of the thorny shrubs. This study also highlighted a potential of thorny shrub application in vegetation management and planning in temperate lowland cultural landscapes, which are often influenced by high densities of large herbivores. Some thorny shrub species (wild rose and hawthorn) can withstand browsing pressure and provide protection to seedlings of tree and shrub species [45]. The utilization of such protection from an unpalatable neighbouring species, known as facilitation, has been studied in several plant-herbivore systems [46]. We have shown that associational resistance can be very effective for some deciduous tree species.

The results of our study are comparable with studies of broadleaved lowland forests [47], although some of our study plots are located above $700 \mathrm{~m}$ a.s.l., which is the limit for lowland forests in the Czech Republic [48]. In our study area, common ash formed the majority of seedlings and saplings, followed by wild cherry and sycamore maple. Ash and maples' winged seeds can probably facilitate seed dispersal over longer distances from their maternal trees. Wild cherry seeds are mainly spread by birds and mammals (such as foxes) [49]. In accordance with our results, the predominance of common ash during the colonization of open areas in landscapes was also confirmed by study [50], which evaluated woodland expansion on former agricultural land. This mentioned study also revealed that the intensity of damage from browsing was least when under the shelter of shrubs. A similar recent situation was presented by Vera [6] in the National Park Dölby Söderskog, where ash, elm, and sycamore maple dominated in the composition of natural regeneration, mainly in the height category of less than 0.5 metres. Study [51] supported our findings by a report of thorny shrub thickets of blackthorn and hawthorn offering key physical protection against large herbivores in lowland broadleaved forests and in browsed woodlands.

In our study, the effects of different species of thorny shrubs varied. The probability of regeneration grew with an increase in cover and in the proportion of two thorny shrub species-wild rose and hawthorn. In contrast, blackthorn can negatively impact the probability of regeneration, and where blackthorn dominated with high cover, no seedlings and saplings were present at all. However, the distinct species' roles do not seem to be universal, as blackthorn can provide significant protection to pedunculate oak seedlings and saplings [52]. However, the seedlings in that mentioned experimental study were artificially planted under the blackthorn shrubs, whereas we surveyed the occurrence of natural regeneration in our study area. Hawthorn appeared to be important for tree regeneration in this system, as its presence, alone and in combination with wild rose, was associated with higher numbers of tree seedlings and saplings. At the same time, hawthorn had a negative effect on the proportion of damaged seedlings and saplings i.e., it had a positive effect on their protection.

The protective role of thorny shrubs from browsers is important in mixed shrub stands, but with hawthorn, often only wild large herbivores could damage the shrubs. The protective role of shrubs may also interact with the community, along with other vegetation and landscape factors [53]. We did not prove in our study area that pedunculate oak regenerated well under the protection of thorny shrubs, despite the fact that our study area is the part of geographical area of pedunculate oak occurrence [54]. We found only one sapling of pedunculate oak with a height of 1.5 metres, even though there were mature trees of oak in the vicinity of our study plots.

The heights of seedlings and saplings decreased with the increasing heights of thorny bushes. This could be related to the reduction of light availability under taller shrubs. Tree species with higher shade tolerance, such as those at our site, may benefit more from association with shrubs, which offer refuge from browsing but will not affect seedling and sapling growth to the same degree as with the less shade-tolerant tree species. We presumed that shrub cover would have a greater effect on seedling 
and sapling heights than the heights of shrubs, but our results show a stronger relationship between the heights of seedlings and saplings and the heights of thorny shrubs.

Our models 3, 4, and 6 indicated an important role of thorny shrubs as a protection against browsing of large herbivores. However, the protective role of thorny shrubs in the survival and growth of tree seedlings and saplings appeared less decisive than described by Vera [6], who claimed that tree seedlings and saplings were actually protected from deer and livestock by the thorny shrubs, which served as fences. We found that thorny shrubs only reduced browsing damage on tree seedlings and saplings at the high cover rates, because the large herbivores were able to penetrate deeply into areas covered by smaller or less dense shrubs. A higher proportion of wild rose seemed to reduce the ability of browsers to penetrate deeply into the grove, and this reduced the damage. In the case of blackthorn, sufficient protection was only achieved in very dense and impenetrable thickets. However, these conditions were unfavourable for regeneration and no seedlings and saplings were present. Only in the case of dense thickets formed by hawthorn could we attribute its protective role to the survival of tree seedlings and saplings. Similarly, in the Mediterranean area, hawthorn is the most efficient species in facilitating the establishment and development of tree species' seedlings [55].

In our study, blackthorn did not provide a suitable habitat for tree regeneration, in contrast with several studies [56]. There was actually no vegetation but only bare soil under the blackthorn thickets (pers. exp.). We also did not observe any of the tree species with heavy seeds, or the pioneer species such as birch, goat willow, or aspen, producing large numbers of tiny winged or fluffy seeds, to regenerate under thorny shrubs. According to our findings, the tree species with winged seeds heavier than the light seeds from pioneer tree species regenerated best under thorny shrubs. The successful regeneration and growth was also likely related to the light demands of the tree species. All the assessed tree species that successfully regenerated under the shrubs can tolerate a substantial degree of shade (better than oak, birch, or aspen), and can thus survive and grow under the canopies of the shrubs. Both common ash and maple are shade-tolerant tree species in their early years, and thus they are able to grow under the shelter of shrubs [57].

Large herbivores affected the formation of wood pastures and the lack of browsing refuges limited sapling establishment, as shown in test plots of artificially planted seedlings of shrubs (thorny and thorn-less) and two hardwood species, oak and ash [58]. This could also be seen in the growth assessment of oak seedlings planted under thorny shrubs. Manning et al. [59] confirmed that too much and too little browsing can be threats- too much leads to a lack of recruitment, and too little can turn open-wood pastures into denser forest ecosystems.

On the other hand, thorny shrubs need not play such a decisive role in the regeneration of lowland forests. According to data from the Bialowieza Forest in Poland, lowland forest gaps were also found to regenerate without the presence of protective shrubs, even though ungulates prefer vegetation gaps to closed forest for their browsing [60]. While Vera [6] claimed that oak also regenerates on the fringes of scrubs but not (or hardly) in a mature forest, pollen data from the Bialowieza Forest indicate that pedunculate oak (Quercus robur L.) is stand-dominant, and not just an ephemeral, mid-successional species. However, we have to take into consideration that oak is a long-lived pioneer species, which can also regenerate after fire. The natural succession in the gaps in forests made through anthropogenic activity is formed by pioneer tree species such as birch (Betula spp.), willow (Salix spp.), and poplar (Populus spp.), which are later replaced by Norway spruce, pine, and oaks [61]. Abandoned agricultural land in the vicinity of the Bialowieza Forest is not covered by thorny shrubs, but by a mosaic of communities of tall grasses and perennial herbs, and by clumps of bushy willows as well as numerous wooded groves dominated by pioneer tree species such as birch, aspen (Populus tremula L.), black alder (Alnus glutinosa (L.) Gaertn.), and goat willow (Salix caprea L.) [62].

Although Vera's theory is controversial and not accepted by all scientists, it is inspirational for future research, by our opinion. It is not only the question of what the primeval lowland forests looked like which has provoked increased interest in research trying to find confirmation or rejection of Vera's hypothesis, but also the research into the relationships among big grazers, thorny bushes, and forest 
regeneration. Therefore, we believe that our study can contribute to the debate over the role of thorny shrubs in the natural regeneration of deciduous forest trees under pressure from large herbivores. While some authors [63] talk of an open park-like landscape, where tree regeneration can only be successful under the protection of thorny shrubs, other authors attribute a much less critical role to wild large herbivores or debate the degree of the landscape openness [64], therefore also rendering the protective role of thorny shrubs for successful regeneration less important [7]. Even if the landscapes were more open, the physical effects of large herbivore activity, such as trampling and digging [65], and lower concentrations of atmospheric $\mathrm{CO}_{2}$ [66-69] may have contributed to this pattern.

A high density of large carnivores can be solved by a large-scale game management system in a traditional sport hunting culture, as pointed out by the first report of a successful solution for reducing the browsing damage of deer via an intense hunting effort in Germany [70]. However, in some European countries such as in the Czech Republic, hunters seek to maintain high large herbivores densities (despite browsing damage) because of their subjective interests on traditional hunting as a hobby [71]. This issue needs to be discussed widely in conservation and forestry literature. The browsing pressure of large herbivores on tree regeneration can be successfully mitigated by large predators, such as wolves [72]. This is not timely in our study area, where large predators are absent, but we can register a slow recovery of large carnivores in many of Europe's modern human-dominated landscapes [73,74]. Despite the facts that predator-prey interactions in anthropogenic landscapes will be highly context-dependent and human actions will often attenuate the ecological effects of large carnivores $[75,76]$, recovery of large predators in our study area would probably support an ecological role of thorny shrubs in the protection of natural tree regeneration.

\section{Conclusions}

Our study contributes to the debate about the important ecological relationships between some species of large herbivores and temperate forest regeneration. Our study area was covered by a mosaic of thorny shrubs, with trees regenerating under their canopy, and with maternal trees in the vicinity. Not all thorny shrubs played a key role in the associational resistance of the tree seedlings and saplings. While blackthorn did not provide a suitable refuge for the regeneration of deciduous tree species against the browsing pressures of red deer and sika deer, hawthorn and wild rose were more suitable for their regeneration. Even though the large ungulates could occasionally penetrate into the interior of shrub thickets formed by both hawthorn and wild rose, thus causing damage by browsing, the dense groves of both shrub species were more effective in protecting seedlings and saplings from browsers than more open shrub groves. In accordance with Vera's hypothesis, thorny shrubs provided the best conditions for the regeneration of forest trees under pressure from some species of large herbivores. However, we confirmed this only for some regenerated tree species (common ash and wild cherry).

For sustainable landscape management, we need to understand the factors that can reduce damage on tree regeneration caused by large herbivores in general. Here, we distinguish the effects of thorny shrub coverage, the composition of the shrubs, and the role of shrub heights in the survival and growth of tree seedlings and saplings. These findings can be used in temperate vegetation management to aid regeneration in areas with high populations of red deer and sika deer, and in landscape planning based on using the thorny shrubs in initiating forest stand regeneration in the frame of ecological restoration projects.

Author Contributions: L.S. and I.M. prepared a study design; methodology was developed by LS., I.M., and O.T.; J.H. was responsible for statistical analyses; L.J. was responsible for validation of statistics; field investigation was done by L.S., I.M., L.J., and O.T.; L.S. and I.M. wrote an original draft; O.T. was responsible for writing-review editing; project administration was done by L.J.

Funding: This study was supported by the grant Significant Trees-Living Symbols of National and Cultural Identity, No. DG18P020VV027, funded by the Ministry of Culture of the Czech Republic from NAKI II (Programme to Support Applied Research and Experimental Development of National and Cultural Identity). 
Acknowledgments: Authors give thanks to Radka Stolarikova and Barbora Klementova for their assistance with fieldwork, and the staff of Division Karlovy Vary of Vojenske lesy a statky (Military Forests and Farms) for valuable technical support in the field. Authors are grateful to the Academic Editor and Reviewers for valuable comments to the manuscript.

Conflicts of Interest: The authors declare no conflict of interest.

\section{References}

1. Wortley, L.; Hero, J.-M.; Howes, M. Evaluating ecological restoration success: A review of the literature. Restor. Ecol. 2013, 21, 537-543. [CrossRef]

2. Maes, S.L.; Perring, M.P.; Vanhellemont, M.; Depauw, L.; Van den Bulcke, J.; Brumelis, G.; Brunet, J.; Decocq, G.; den Ouden, J.; Hardtle, W.; et al. Environmental drivers interactively affect individual tree growth across temperate European forests. Glob. Chang. Biol. 2019, 25, 201-217. [CrossRef] [PubMed]

3. Bernhardt-Romermann, M.; Baeten, L.; Craven, D.; De Frenne, P.; Hedl, R.; Lenoir, J.; Bert, D.; Brunet, J.; Chudomelova, M.; Decocq, G.; et al. Drivers of temporal changes in temperate forest plant diversity vary across spatial scales. Glob. Chang. Biol. 2015, 21, 3726-3737. [CrossRef] [PubMed]

4. Dansgaard, W.; White, J.W.C.; Johnsen, S.J. The abrupt termination of the Younger Dryas climate event. Nature 1989, 339, 532. [CrossRef]

5. Svenning, J.-C.H. A review of natural vegetation openness in north-western Europe. Biol. Conserv. 2002, 104, 133-148. [CrossRef]

6. Vera, F.W.M. Grazing Ecology and Forest History; CAB International: Wallingford, UK, 2000; ISBN 0-85199-442-3.

7. Birks, H.J.B. Mind the gap: How open were European primeval forests? Trends Ecol. Evol. 2005, 20, 154-156. [CrossRef] [PubMed]

8. Mitchell, F.J.G. How open were European primeval forests? Hypothesis testing using palaeoecological data. J. Ecol. 2005, 93, 168-177. [CrossRef]

9. Bakker, E.S.; Gill, J.L.; Johnson, C.H.N.; Vera, F.W.M.; Sandom, C.H.J.; Asner, G.P.; Svenning, J.-C.H. Combining paleo-data and modern exclosure experiments to assess the impact of megafauna extinctions on woody vegetation. Proc. Natl. Acad. Sci. USA 2016, 113, 847-855. [CrossRef]

10. Kuijper, D.P.J.; de Kleine, C.; Churski, M.; van Hooft, P.; Bubnicki, J.; Jedrzejewska, B. Landscape of fear in Europe: Wolves affect spatial patterns of ungulate browsing in Bialowieza Primeval Forest, Poland. Ecography 2013, 36, 1263-1275. [CrossRef]

11. Szabó, P. Open Woodland in Europe in the Mesolithic and in the Middle Ages: Can there be a connection? For. Ecol. Manag. 2009, 257, 2327-2330. [CrossRef]

12. Bakker, E.S.; Olff, H.; Vandenberghe, C.; De Maeyer, K.; Smit, R.; Gleichman, J.M.; Vera, F.W.M. Ecological anachronism in the recruitment of temperate light-demanding tree species in wooded pasture. J. Appl. Ecol. 2004, 41, 571-582. [CrossRef]

13. Kilianova, H.; Pechanec, V.; Brus, J.; Kirchner, K.; Machar, I. Analysis of the development of land use in the Morava River floodplain, with special emphasis on the landscape matrix. Morav. Geogr. Rep. 2017, 25, 46-59. [CrossRef]

14. Simon, J.; Machar, I.; Bucek, A. Linking the historical research with the growth simulation model of hardwood floodplain forests. Pol. J. Ecol. 2014, 62, 273-288. [CrossRef]

15. Kuijper, D.P.J.; Bubnicki, J.W.; Churski, M.; Cromsigt, J.P.G.M. Multi-trophic interactions in anthropogenic landscapes: The devil is in the detail. Proc. R. Soc. B-Biol. Sci. 2016, 283. [CrossRef] [PubMed]

16. Cermak, P.; Beranova, P.; Oralkova, J.; Horsak, P.; Plsek, J. Relationships between browsing damage and the species dominance by the highly food-attractive and less food-attractive trees. Acta Universitatis Agriculturae Mendelianae Brunensis 2011, 59, 29-36. [CrossRef]

17. Hedwall, P.-O.; Churski, M.; Jedrzejewska, B.; Miscicki, S.; Kuijper, D.P.J. Functional composition of temperate forest trees under chronic ungulate herbivory. J. Veg. Sci. 2018, 29, 179-188. [CrossRef]

18. Spitzer, L.; Konvicka, M.; Benes, J.; Tropek, R.; Tuf, I.H.; Tufova, J. Does closure of traditionally managed open woodlands threaten epigeic invertebrates? Effects of coppicing and high deer densities. Biol. Conserv. 2008, 14, 827-837. [CrossRef] 
19. Czortek, P.; Ratynska, H.; Dyderski, M.K.; Jagodzinski, A.M.; Orczewska, A.; Jaroszewicz, B. Cessation of livestock grazing and windthrow drive a shift in plant species composition in the Western Tatra Mts. Tuxenia 2018, 38, 177-196. [CrossRef]

20. Machar, I. Changes in ecological stability and biodiversity in a floodplain landscape. In Applying Landscape Ecology in Conservation and Management of the Floodplain Forest (Czech Republic); Machar, I., Ed.; Palacky University: Olomouc, Czech Republic, 2012; pp. 73-87. ISBN 978-80-244-2997-7.

21. Machar, I.; Cermak, P.; Pechanec, V. Ungulate Browsing Limits Bird Diversity of the Central European Hardwood Floodplain Forests. Forests 2018, 9, 373. [CrossRef]

22. Eichhorn, M.P.; Ryding, J.; Smith, M.J.; Gill, R.M.A.; Siriwardena, G.M.; Fuller, R.J. Effects of deer on woodland structure revealed through terrestrial laser scanning. J. Appl. Ecol. 2017, 54, 1615-1626. [CrossRef]

23. Kovarik, P.; Kutal, M.; Machar, I. Sheep and wolves: Is the occurrence of large predators a limiting factor for sheep grazing in the Czech Carpathians? J. Nat. Conserv. 2014, 22, 479-486. [CrossRef]

24. Côté, S.D.; Rooney, T.P.; Tremblay, J.-P.; Dussault, C.; Waller, D.M. Ecological impacts of deer overabundance. Annu. Rev. Ecol. Evol. Syst. 2004, 35, 113-147. [CrossRef]

25. Kuijper, D.P.J.; Cromsigt, J.P.G.M.; Jędrzejewska, B.; Miścicki, S.; Churski, M.; Jędrzejewski, W.; Kweczlich, I. Bottom-up versus top-down control of tree regeneration in the Białowieža Primeval Forest, Poland. J. Ecol. 2010, 98, 888-899. [CrossRef]

26. Vandenberghe, C.; Frelechoux, F.; Gadallah, F.; Buttler, A. Competitive effects of herbaceous vegetation on tree seedling emergence, growth and survival: Does gap size matter? J. Veg. Sci. 2006, 17, 481-488. [CrossRef]

27. Holl, K.; Smith, M. Scottish upland forest: History lessons for the future. For. Ecol. Manag. 2007, 249 , 45-53. [CrossRef]

28. Gill, R.M.A. A review of damage by mammals in north temperature forests. 3. Impact on trees and forests. Forestry 1992, 65, 363-388. [CrossRef]

29. Van der Plas, F.; Ratcliffe, S.; Ruiz-Benito, P.; Scherer-Lorenzen, M.; Verheyen, K.; Wirth, C.; Zavala, M.A.; Ampoorter, E.; Baeten, L.; Barbaro, L.; et al. Continental mapping of forest ecosystem functions reveals a high but unrealised potential for forest multifunctionality. Ecol. Lett. 2018, 21, 31-42. [CrossRef]

30. Machar, I.; Kulhavy, A.; Sejak, J.; Pechanec, V. Conservation effectiveness and monetary value of floodplain forests habitats in the Czech Republic. Rep. For. Res.-Zpravy Lesnickeho Vyzkumu 2018, 63, 206-213.

31. Machar, I. Attempt to summarize the problems: Is a sustainable management of floodplain forest geobiocenoses possible? In Biodiversity and Target Management of Floodplain Forests in the Morava River Basin (Czech Republic); Machar, I., Ed.; Palacky University: Olomouc, Czech Republic, 2010; pp. 189-226. ISBN 978-80-244-2530-6.

32. Ratcliffe, S.; Wirth, C.; Jucker, T.; van der Plas, F.; Scherer-Lorenzen, M.; Verheyen, K.; Allan, E.; Benavides, R.; Bruelheide, H.; Ohse, B.; et al. Biodiversity and ecosystem functioning relations in European forests depend on environmental context. Ecol. Lett. 2017, 20, 1414-1426. [CrossRef]

33. Cizek, O.; Vrba, P.; Benes, J.; Hrazsky, Z.; Koptik, J.; Kucera, T.; Marhoul, P.; Zamecnik, J.; Konvicka, M. Conservation Potential of Abandoned Military Areas Matches That of Established Reserves: Plants and Butterflies in the Czech Republic. PLoS ONE 2013, 8, e53124. [CrossRef]

34. Machar, I.; Simon, J.; Rejsek, K.; Pechanec, V.; Brus, J.; Kilianova, H. Assessment of Forest Management in Protected Areas Based on Multidisciplinary Research. Forests 2016, 7, 285. [CrossRef]

35. Perea, R.; López-Sánchez, A.; Roig, S. The use of shrub cover to preserve Mediterranean oak dehesas: A comparison between sheep, cattle and wild ungulate management. Appl. Veg. Sci. 2016, 19, $244-253$. [CrossRef]

36. Ramírez, J.A.; Díaz, M. The role of temporal shrub encroachment for the maintenance of Spanish holm oak Quercus ilex dehesas. For. Ecol. Manag. 2008, 255, 1976-1983. [CrossRef]

37. Miko, L. Nature and landscape protection in the European context. In Ochrana Prirody a Krajiny $v$ Ceske Republice, Vols I and II; Machar, I., Drobilova, L., Eds.; Palacky University: Olomouc, Czech Republic, 2012; pp. 43-49, ISBN 978-80-244-3041-6.

38. Pechanec, V.; Machar, I.; Pohanka, T.; Oprsal, Z.; Petrovič, F.; Svajda, J.; Salek, L.; Chobot, K.; Filippovova, J.; Cudlin, P.; et al. Effectiveness of Natura 2000 system for habitat types protection: A case study from the Czech Republic. Nat. Conserv.-Bulg. 2018, 24, 21-41. [CrossRef] 
39. Machar, I. Protection of nature and landscapes in the Czech Republic Selected current issues and possibilities of their solution. In Ochrana Prirody a Krajiny v Ceske Republice, Vols I and II; Machar, I., Drobilova, L., Eds.; Palacky University: Olomouc, Czech Republic, 2012; ISBN 978-80-244-3041-6.

40. Rajnyšová, R.; Tomášek, V.; Košňař, A.; Macháček, Z. Comparison of population ungulates in areas with different type of environment-Preliminary report. In Proceedings of the Conference Coyous 2014, Konference Mladých Vědeckých Pracovníků, Kostelec nad Černými Lesy, Czech Republic, 28 May 2014; Marušák, R., Dvořák, J., Natov, P., Eds.; ČZU v Praze: Prague, Czech Republic, 2014; pp. 30-40.

41. Kalb, D.M.; Bowman, J.L.; DeYoung, R.W. Dietary resource use and competition between white-tailed deer and introduced sika deer. Wildl. Res. 2018, 45, 457-472. [CrossRef]

42. Vacek, Z.; Vacek, S.; Bilek, L.; Kral, J.; Remes, J.; Bulusek, D.; Kralicek, I. Ungulate impact on natural regeneration in spruce-beech-fir stands in Cerny Dul nature reserve in the Orlicke Hory mountains, Case study from Central Sudetes. Forests 2014, 5, 2929-2946. [CrossRef]

43. StataCorp. Stata Statistical Software: Release 15; StataCorp LLC: College Station, TX, USA, 2017.

44. Ramirez, J.I.; Jansen, P.A.; den Ouden, J.; Goudzwaard, L.; Poorter, L. Long-term effects of wild ungulates on the structure, composition and succession of temperate forests. For. Ecol. Manag. 2019, 432, 478-488. [CrossRef]

45. De Jager, N.R.; Cogger, B.J.; Thomsen, M.A. Interactive effects of flooding and deer (Odocoileus virginianus) browsing on floodplain forest recruitment. For. Ecol. Manag. 2013, 303, 11-19. [CrossRef]

46. Smit, C.h.; Ruifrok, J.L.; van Klink, R.; Olff, H. Rewilding with large herbivores: The importance of grazing refuges for sapling establishment and wood-pasture formation. Biol. Conserv. 2015, 182, 134-142. [CrossRef]

47. Machar, I. Conservation and Management of Floodplain Forests in the Protected Landscape Area Litovelske Pomoravi (Czech Republic) Introduction. In Conservation and Management of Floodplain Forests in the Protected Landscape Area Litovelske Pomoravi (Czech Republic); Machar, I., Ed.; Palacky University: Olomouc, Czech Republic, 2009; pp. 7-108, ISBN 978-80-244-2355-5.

48. Kusbach, A.; Friedl, M.; Zouhar, V.; Mikita, T.; Šebesta, J. Assessing Forest Classification in a Landscape-Level Framework: An Example from Central European Forests. Forests 2017, 8, 461. [CrossRef]

49. Petrokas, R. Prerequisites for the reproduction of wild cherry (Prunus avium L.). Balt. For. 2010, 16, 139-153.

50. Van Uytvanck, J.; Decleer, K.; Hoffmann, M. Establishment patterns of woody species in low-intensity grazed pastures after the cessation of intensive agricultural use. For. Ecol. Manag. 2008, 256, 106-113. [CrossRef]

51. Smit, C.h.; Ruifrok, J.L. From protégé to nurse plant: Establishment of thorny shrubs in grazed temperate woodlands. J. Veg. Sci. 2011, 22, 377-386. [CrossRef]

52. Jensen, A.M.; Götmark, F.; Löf, M. Shrubs protect oak seedlings against ungulate browsing in temperate broadleaved forests of conservation interest: A field experiment. For. Ecol. Manag. 2012, 266, 187-193. [CrossRef]

53. Kilianova, H.; Pechanec, V.; Svobodova, J.; Machar, I. Analysis of the evolution of the floodplain forests in the aluvium of the Morava river. In Proceedings of the 12th International Multidisciplinary Scientific Geoconference, SGEM 2012, Albena, Bulgaria, 17 June 2012; SGEM: Albena, Bulgaria, 2012; Volume 4.

54. Salekl, L.; Sivacioglu, A.; Topacoglu, O.; Zahradnile, D.; Jerabkoval, L.; Machar, I. Crowns of old remnant oak standards. Fresenius Environ. Bull. 2017, 26, 4023-4032.

55. Alias, S.; Bianchi, L.; Calamini, G.; Gregori, E.; Sioni, S. Shrub facilitation of Quercus ilex and Quercus pubescens regeneration in a wooded pasture in Central Sardinia (Italy). iForest 2010, 3, 16-22. [CrossRef]

56. Simon, J.; Machar, I.; Brus, J.; Pechanec, V. Combining a growth-simulation model with acoustic-wood tomography as a decision-support tool for adaptive management and conservation of forest ecosystems. Ecol. Inform. 2015, 30, 309-312. [CrossRef]

57. Uradnicek, L.; Madera, P.; Ticha, S.; Koblizek, J. Woody Plants of the Czech Republic; Lesnicka prace: Kostelec nad Cernymi lesy, Czech Republic, 2010; pp. 1-368, ISBN 978-80-87154-45-8.

58. Ramirez, J.I.; Jansen, P.A.; Poorter, L. Effects of wild ungulates on the regeneration, structure and functioning of temperate forests: A semi-quantitative review. For. Ecol. Manag. 2018, 424, 406-419. [CrossRef]

59. Manning, A.D.; Fischer, J.; Lindenmayer, D.B. Scattered trees are keystone structures-Implication for conservation. Biol. Conserv. 2006, 132, 311-321. [CrossRef]

60. Kuijper, D.P.J.; Cromsigt, J.P.G.M.; Churski, M.; Adam, B.; Jędrzejewska, B.; Jędrzejewski, W. Do ungulate preferentially feed in forest gaps in European temperate forest. For. Ecol. Manag. 2009, 258, 1528-1535. [CrossRef] 
61. Mitchell, F.J.G.; Cole, E. Reconstruction of long-term successional dynamics of temperate woodland in Bialowieza Forest. Pol. J. Ecol. 1998, 86, 1042-1059. [CrossRef]

62. Bobiec, A.; Kuijper, D.P.J.; Niklasson, M.; Romankiewicz, A.; Solecka, K. Oak (Quercus robur L.) regeneration in early successional woodland grazed by wild ungulates in the absence of livestock. For. Ecol. Manag. 2011, 262, 780-790. [CrossRef]

63. Pellerin, M.; Said, S.; Richard, E.; Hamann, J.-L. Impact of deer on temperate forest vegetation and woody debris as protection of forest regeneration against browsing. For. Ecol. Manag. 2010, 260, 429-437. [CrossRef]

64. Whitehouse, N.J.; Smith, D. How fragmented was the British Holocene wildwood? Perspectives on the "Vera" grazing debate from the fossil beetle record. Quat. Sci. Rev. 2010, 29, 539-553. [CrossRef]

65. Zimov, S.A.; Chuprynin, V.I.; Oreshko, A.P.; Chapin, F.S.; Reynolds, J.F.; Chapin, M.C. Steppe-tundra transition: A herbivore-driven biome shift at the end of the Pleistocene. Am. Nat. 1995, 14, 765-794. [CrossRef]

66. Kgope, B.S.; Bond, W.J.; Midgley, G.F. Growth responses of African savanna trees implicate atmospheric $\mathrm{CO}_{2}$ as a driver of past and current changes in savanna tree cover. Aust. Ecol. 2010, 35, 451-463. [CrossRef]

67. Machar, I.; Vozenilek, V.; Kirchner, K.; Vlckova, V.; Bucek, A. Biogeographic model of climate conditions for vegetation zones in Czechia. Geografie 2017, 122, 64-82.

68. Kopecka, V.; Machar, I.; Bucek, A.; Kopecky, A. The Impact of Climate Changes on Sugar Beet Growing Conditions in the Czech Republic. Listy Cukrovarnicke a Reparske 2013, 129, 326-329.

69. Machar, I.; Vlckova, V.; Bucek, A.; Vozenilek, V.; Salek, L.; Jerabkova, L. Modelling of climate conditions in forest vegetation zones as a support tool for forest management strategy in European beech dominated forests. Forests 2017, 8, 82. [CrossRef]

70. Hothorn, T.; Müller, J. Large-scale reduction of ungulate browsing by managed sport hunting. For. Ecol. Manag. 2010, 260, 1416-1423. [CrossRef]

71. Cerveny, J.; Krojerova-Prokesova, J.; Kusta, T.; Koubek, P. The change in the attitudes of Czech hunters towards Eurasian lynx: Is poaching restricting lynx population growth? J. Nat. Conserv. 2019, 47, $28-37$. [CrossRef]

72. Kuijper, D.P.J.; Sahlen, E.; Elmhagen, B.; Chamaille-Jammes, S.; Sand, H.; Lone, K.; Cromsigt, J.P.G.M. Paws without claws? Ecological effects of large carnivores in anthropogenic landscapes. Proc. R. Soc. B-Biol. Sci. 2016, 283. [CrossRef] [PubMed]

73. Oprsal, Z.; Harmacek, J.; Pavlik, P.; Machar, I. What Factors Can Influence the Expansion of Protected Areas around the World in the Context of International Environmental and Development Goals? Problemy Ekorozwoju 2018, 13, 145-157.

74. Chapron, G.; Kaczensky, P.; Linnell, J.D.C.; von Arx, M.; Huber, D.; Andren, H.; Lopez-Bao, J.V.; Adamec, M.; Alvares, F.; Anders, O.; et al. Recovery of large carnivores in Europe's modern human-dominated landscapes. Science 2014, 346, 1517-1519. [CrossRef] [PubMed]

75. Kuijper, D.P.J. Lack of natural control mechanisms increases wildlife-forestry conflict in managed temperate European forest systems. Eur. J. For. Res. 2011, 130, 895-909. [CrossRef]

76. Jia, S.; Wang, X.; Yuan, Z.; Lin, F.; Ye, J.; Hao, Z.; Luskin, M.S. Global signal of top-down control of terrestrial plant communities by herbivores. Proc. Natl. Acad. Sci. USA 2018, 115, 6237-6242. [CrossRef]

(C) 2019 by the authors. Licensee MDPI, Basel, Switzerland. This article is an open access article distributed under the terms and conditions of the Creative Commons Attribution (CC BY) license (http://creativecommons.org/licenses/by/4.0/). 